\title{
SISTEM PAKAR MENDIAGNOSA PENYAKIT PADA UNGGAS DENGAN METODE TEOREMA BAYES BERBASIS WEB
}

\author{
Achmad Rido'i' ${ }^{1)}$, Retno Wardhani' ${ }^{2)}$, Masruroh ${ }^{3)}$ \\ ${ }^{1)}$ Mahasiswa Program Studi Teknik Informatika, Fakultas Teknik, Universitas Islam Lamongan \\ ${ }^{2)}$ Dosen Program Studi Teknik Informatika, Fakultas Teknik, Universitas Islam Lamongan \\ Jl. Veteran No. 53 A Lamongan \\ Telp. (0332)324706 \\ E-Mail : ahmadridoi14@gmail.com ${ }^{1}, \underline{\text { retzno@yahoo.com }}{ }^{2}, \underline{\text { ismi_masruroh@yahoo.com }}{ }^{3}$
}

\begin{abstract}
Poultry has many benefits such as its eggs and meat that cannot be separated from the needs of daily consumption. However, there is a major problem that almost experienced every year for the breders. The disease in poultry is a serious problem that becomes obstacles for the breeders. Based on this problem, the application maker made an expert system application to diagnose the disease in poultry with Bayes theorem method. This application is expected to help the breeders in diagnosing the disease in poultry, therefore the death of poultry can be minimized. This application has been successfully designed and implemented using notepad ++ and php MySQL through several steps of main menu design system, those are; consultation, diseases, and aid. The coding making is done in notepad ++ application. Then making the database is done in php MySQL. The result reveals that this application is made to identify the disease based on the existing symptoms. In testing, 10 breeders stated that this application can help diagnose the disease in poultry.
\end{abstract}

Key word: application, web, expert system, bayes theorem method

\section{PENDAHULUAN}

Unggas memiliki banyak manfaat seperti telur dan dagingnya tidak terlepas dari kebutuhan konsumsi sehari-hari. Namun, ada permasalahan utama yang hampir setiap tahunnya dialami bagi peternak-peternak unggas. Penyakit pada unggas merupakan masalah serius yang menjadi rintangan bagi para peternak. Berdasarkan data survey Direktorat Jendral Peternakan dan Kesehatan Hewan tahun 2017 selama bulan maret terakhir terdapat kematian unggas sebanyak 12.136 ekor, yang terdiri atas 1018 ekor ayam kampung, 4618 ekor itik, 2300 ekor Puyuh 3985 ekor Broiler, 15 ekor Kalkun dan 200 ekor ayam petelurBerdasarkan data diatas, angka kematian pada hewan ternak unggas masih sangatlah tinggi. Wabah penyakit tersebut sangat merugikan bagi pengusaha peternakan. Banyak unggas yang baru terkena virus ataupun gejala gejala ringan harus segera dimusnahkan karena minimnya pengetahuan akan jenis penyakit pada unggas. Dari permasalahan tersebut dibuatlah aplikasi untuk mendiagnosa jenis-jenis penyakit unggas. Aplikasi yang akan dibuat akan menggunakan metode Teorema Bayes untuk menghitung kemungkinan gejala penyakit yang ada pada unggas. Metode ini di pilih karena perhitungan Teorema Bayes lebih mudah untuk dipahami, hanya memerlukan perkodean yang sederhana dan lebih cepat dalam perhitungan. Aplikasi ini dibuat berbasis Web dengan menggunakan bahasa pemrograman $p h p$, menggunakan database mysql dan Xampp. Aplikasi tersebut diharapkan dapat membantu proses penanganan gejala penyakit yang di alami para peternak.

Adapun tujuan dan manfaat yang dapat diambil dari tugas akhir ini sebagai berikut:

1. Membuat membuat aplikasi Sistem Pakar Mendiagnosa Penyakit Pada Unggas Dengan Metode Teorema Bayes Berbasis Web?

2. Mendeskripsikan hasil uji coba aplikasi Sistem Pakar Mendiagnosa Penyakit Pada Unggas Dengan Metode Teorema Bayes Berbasis Web?

Teorema Bayes digunakan untuk menghitung probabilitas terjadinya suatu peistiwa berdasarkan pengaruh yang didapat dari hasil observasi. Teorema ini menerangkan hubungan antara probabilitas terjadinya peristiwa A dengan syarat peristiwa B telah terjadi dan probabilitas terjadinya 
peristiwa B dengan syarat peristiwa A telah terjadi. Teorema ini didasarkan pada prinsip bahwa tambahan informasi dapat memperbaiki probabilitas.

$\left.P(H \mid E)=\frac{P(E \mid H) \cdot P(H)}{P(E)} \ldots \ldots \ldots \ldots \ldots \ldots \ldots 1\right)$

Keterangan:

$\mathrm{P}(\mathrm{H} \mid \mathrm{E})=$ probabilitas hipotesis $\mathrm{H}$ jika

diberikan evidence $\mathrm{E}$

$\mathrm{P}(\mathrm{E} \mid \mathrm{H})=$ probabilitas munculnya evidence $\mathrm{E}$

jika diketahui hipotesis $\mathrm{H}$

$\mathrm{P}(\mathrm{H})=$ probabilitas $\mathrm{H}$ tanpa mengandung

evidence apapun

$\mathrm{P}(\mathrm{E})=$ probabilitas evidence $\mathrm{E}$

Sistem pakar merupakan cabang dari artacifial intellegent (AI) yang tertua karena sudah mulai dikembangkan pada pertengahan 1960. Sistem pakar yang muncul pertama kali adalah General-Purpose Problem Solver (GPS) yang dikembangkan oleh Newel dan Simon. Istilah sistem pakar berasal dari knawledge-based expert system.karena sistem pakar untuk memecahkan masalah, dan sistem pakar menggunakan pengetahuan seorang pakar yang di masukkan kedalam komputer.

Xampp adalah perangkat lunak bebas yang mendukung banyak sistem operasi, merupakan campuran dari beberapa program, yang mempunyai fungsi sebagai server yang berdiri sendiri (localhost), yang terdiri dari program MySQL database, Apache HTTP Server, dan penerjemah ditulis dalam bahasa pemograman php dan perl.

PHP merupakan aplikasi perangkat lunak opensource, dimanana kepanjangaan PHP adalah Hypertext Prepocessor yang diatur dalam aturan general purpose licences (GPL). Pemrograman PHP merupakan pemrograman yang sangat cocok dikembangkan dilingkungan web karena bisa diletakkan pada script HTML ataupun sebaliknya

\section{METODOLOGI PENELITIAN}

Tahap analisis pembuatan aplikasi sistem pakar mendiagnosa penyakit pada unggas dilakukan dengan penguraian bagian komponen-komponen dengan maksud mengidentifikasi dan mengevaluasi pemasalahan. Tahap ini meliput:

1. Wawancara atau survey

2. Analilsis

3. Desain

4. Coding program

5. Testing / percobaan

6. Implementasi

7. Dokumentasi

Dalam pembuatan aplikasi sistem pakar mendiagnosa penyakit pada unggas ini menggunakan metode teorema bayes untuk menghitung kemungkinan gejala penyakit yang ada pada unggas. Metode ini di pilih karena perhitungan teorema bayes lebih mudah untuk dipahami, hanya memerlukan perkodean yang sederhana dan lebih cepat dalam perhitungan

Aplikasi sistem pakar mendiagnosa penyakit pada unggas ini dibuat dengan menggunakan basis website melalui tahapan pembuatan menu dan coding serta pembuatan database program menggunakan php mysql.

Diagram konteks merupakan suatu diagram yang menggunakan notasi-notasi untuk menggambarkan arus dari data sistem, yang penggunaannya sangat membantu untuk memahami sistem secara logika, tersruktur dan jelas.seperti Gambar 1.

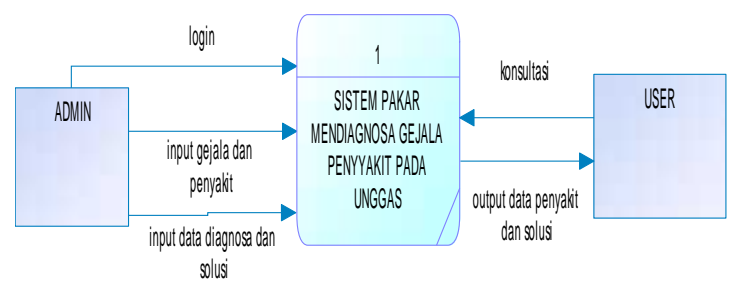

Gambar 1. Diagram Konteks

Pada data flow diagram level 1 dijelaskan tentang proses-proses yang dilakukan admin dan user kepada sistem dan output yang diberikan sistem kepada user, dalam DFD level 0 ini akan dijelaskan bagaimana alur yang akan dilakukan oleh system seperti Gambar 2. 


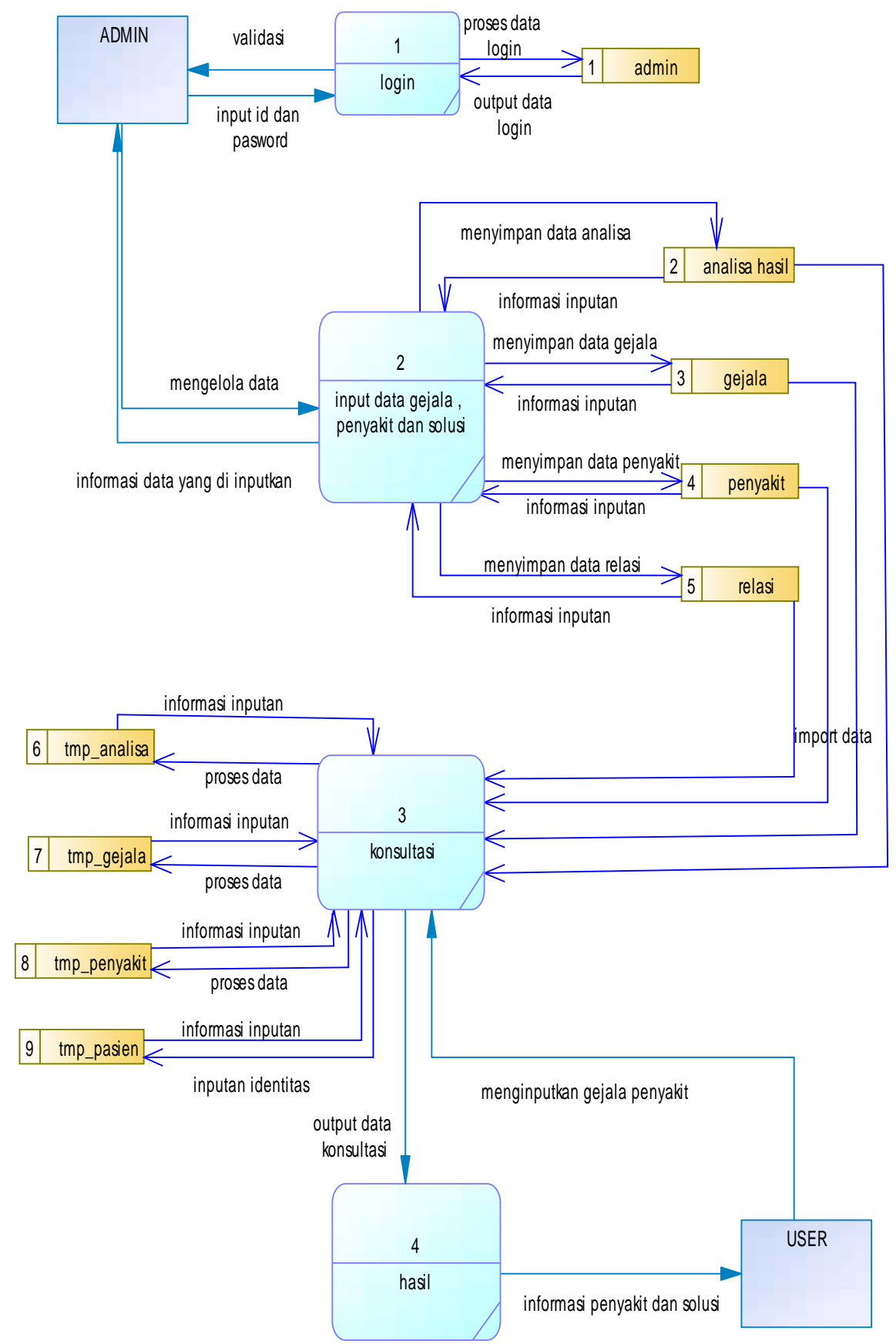

Gambar 2. Data Flow Diagram

Suatu bagan dengan simbol-simbol tertentu yang menggambarkan urutan prosessecara mendetail dan hubungan antara suatu proses (instruksi) dengan lainnya dalam suatu program seperti Gambar 3. 


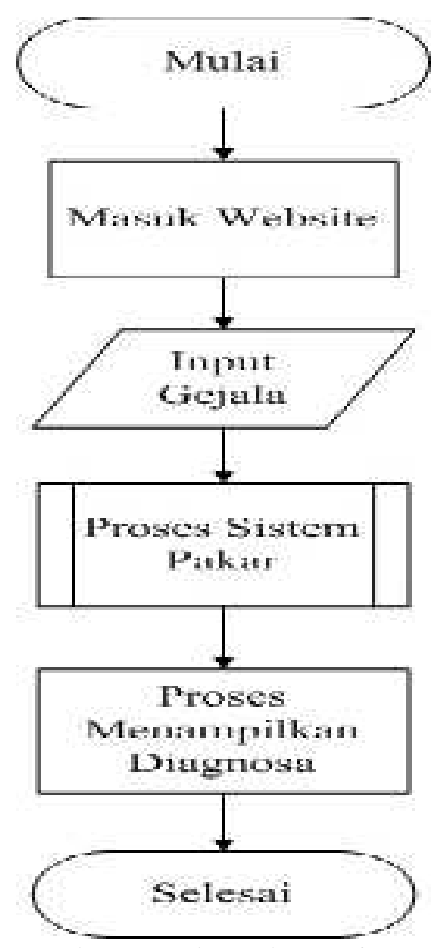

Gambar 3. Flowchart Sistem

\section{HASIL DAN PEMBAHASAN}

Menu utama berfungsi sebagai menu tampilan program yang menampilkan halaman awal pada program SEPERTI Gambar 4.

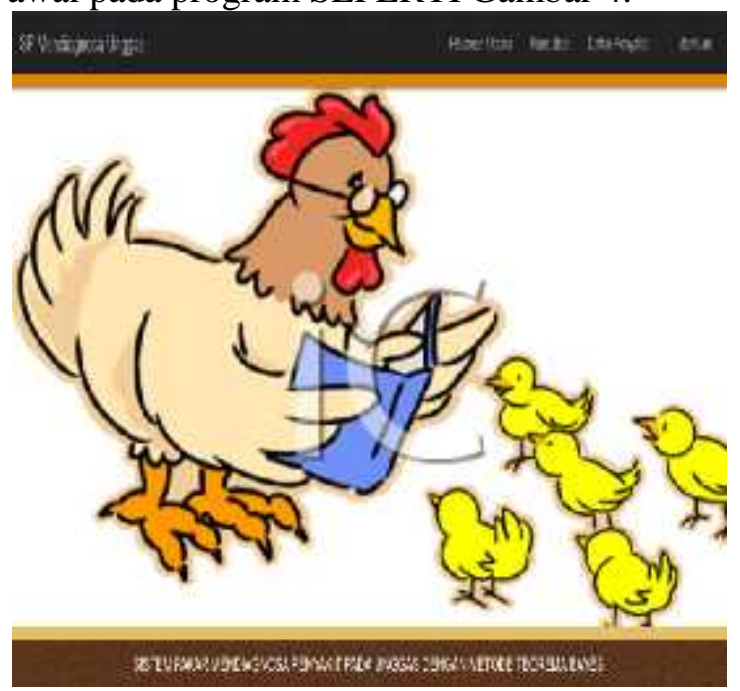

Gambar 4. Menu Utama

Menu konsultasi digunakan untuk user untuk melakukan konsultasi penyakit yang diderita oleh unggas. Berikut tampilan menu utama aplikasi sistem pakar mendiagnosa penyakit pada unggas seperti Gambar 5.

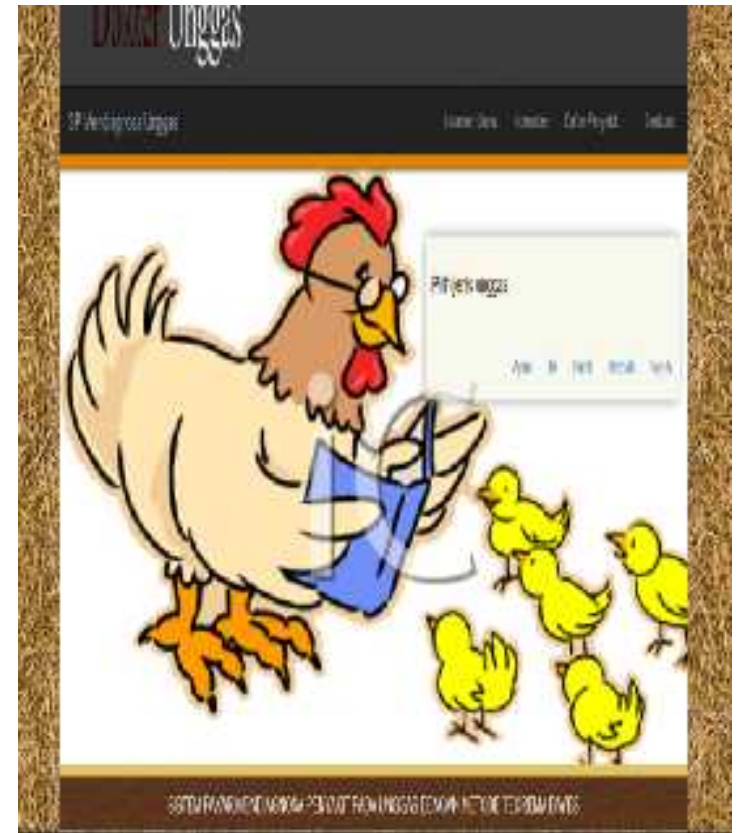

Gambar 5. Menu Konsultasi

Sub menu hasil diagnosa berisi tentang hasil dari pemilihan gejala penyakit yang sudah di pilih. Dalam menu ini di jelaskan tetang penyakit yang di derita unggas dan solusi dari penyakit yang di derita oleh unggas. Berikut gambar dari sub menu hasil diagnose seperti Gambar 6.

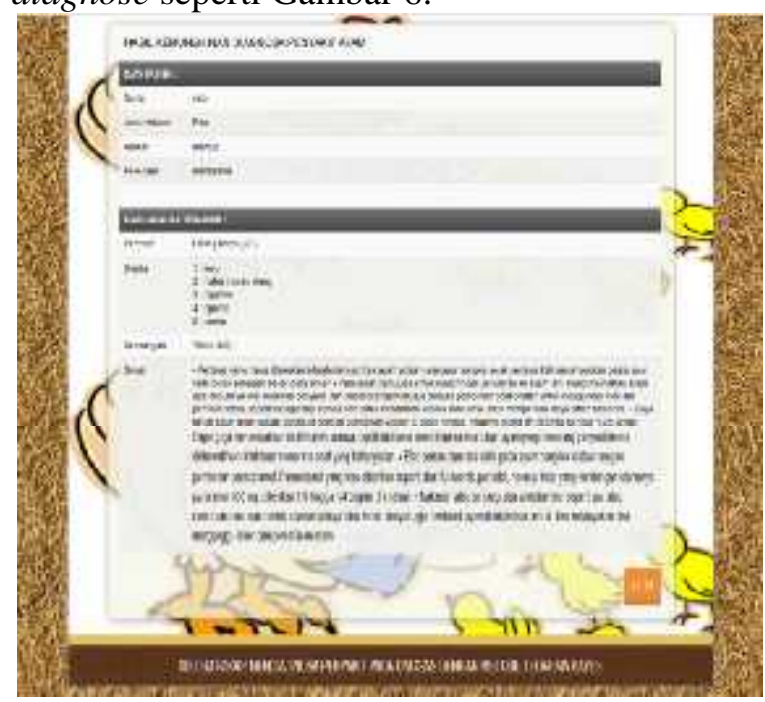

Gambar 6. Sub Menu hasil diagnosa

Pengujian ini dilakukan dengan maksud untuk mengetahui batasan sampai mana program aplikasi ini dapat berjalan, sampai mana aplikasi ini dapat bekerja menampilkan informasi atau output yang diinginkan oleh pengguna. Dalam tahap uji coba ini akan dicari letak dari kekurangan, disamping itu 
pengujian juga bertujuan untuk mengembangkan aplikasi pada tahap yang lebih tinggi.

Gejala yang tampak pada user ada 2 gejala yaitu lemah (G001) dan bulu mudah rontok (G002). Berdasarkan gejala tersebut maka dapat dihitung:

1. Botulism (P001)

Jika probabilitas Botulism (P001) adalah : 0,1

Jika probabilitas gejala memandang penyakit adalah :

- lemah (G001)

- bulu mudah rontok (G002)

$: 0,2$

Perhitungan nilai bayes :

1. $\mathrm{P}(\mathrm{P} 001 \mid \mathrm{G} 001)$

$$
\begin{aligned}
& \mathrm{P}(\mathrm{G} 001 \mid \mathrm{P} 001) * \mathrm{P}(\mathrm{P} 001) \\
& =\frac{\mathrm{P}(\mathrm{G} 001 \mid \mathrm{P} 001) * \mathrm{P}(\mathrm{P} 001)+\mathrm{P}(\mathrm{G} 001 \mid \mathrm{P} 002) * \mathrm{P}(\mathrm{P} 002)+}{\mathrm{P}(\mathrm{P})} \\
& \mathrm{P}(\mathrm{G} 001 \mid \mathrm{P} 003) * \mathrm{P}(\mathrm{P} 003)+\mathrm{P}(\mathrm{G} 001 \mid \mathrm{P} 004) * \mathrm{P}(\mathrm{P} 004)+ \\
& =\frac{0,2 * 0,1}{(0,2 * 0,1)+(0,0 * 0,1)+(0,0 * 0,1)+(0,0 * 0,1)+}= \\
& \frac{0,0}{0,0}=0,38 \\
& (0,0 * 0,1)
\end{aligned}
$$

2. $\mathrm{P}(\mathrm{P} 001 \mid \mathrm{G} 002)$

$$
\begin{array}{r}
=\frac{\mathrm{P}(\mathrm{G} 002 \mid \mathrm{P} 001) * \mathrm{P}(\mathrm{P} 001)}{\mathrm{P}(\mathrm{G} 002 \mid \mathrm{P} 001) * \mathrm{P}(\mathrm{P} 001)+\mathrm{P}(\mathrm{G} 002 \mid \mathrm{P} 002) * \mathrm{P}(\mathrm{P} 002)+} \\
\mathrm{P}(\mathrm{G} 002 \mid \mathrm{P} 003) * \mathrm{P}(\mathrm{P} 003)+\mathrm{P}(\mathrm{G} 002 \mid \mathrm{P} 004) * \mathrm{P}(\mathrm{P} 004)+ \\
\mathrm{P}(\mathrm{G} 002 \mid \mathrm{P} 005) * \mathrm{P}(\mathrm{P} 005) \\
0,2 * 0,1 \\
(0,2 * 0,1)+(0,0 * 0,1)+(0,0 * 0,1)+(0,0 * 0,1)+ \\
(0,0 * 0,1)
\end{array}
$$

0.152

Total bayes $=0,38+0,152=0,532$

Maka perhitungan probabilitas penyakitnya adalah : Penyakit target spot $(\mathrm{P} 01)=0,532 / 2 * 100 \%=26 \%$

Berdasarkan hasil perhitungan di atas maka bebek mengalami botulism dengan presentase $26 \%$, yang sebelumnya user menginputkan gejala lemah dan bulu mudah rontok

Pengujian black box dilakukan untuk memastikan bahwa suatu event atau masukan akan menjalankan proses yang tepat dan menghasilkan output sesuai dengan rancangan. Berikut hasil pengujian black box terhadap aplikasi sistem pakar mendiagnosa penyakit unggas.

\section{Segmen program menu utama}

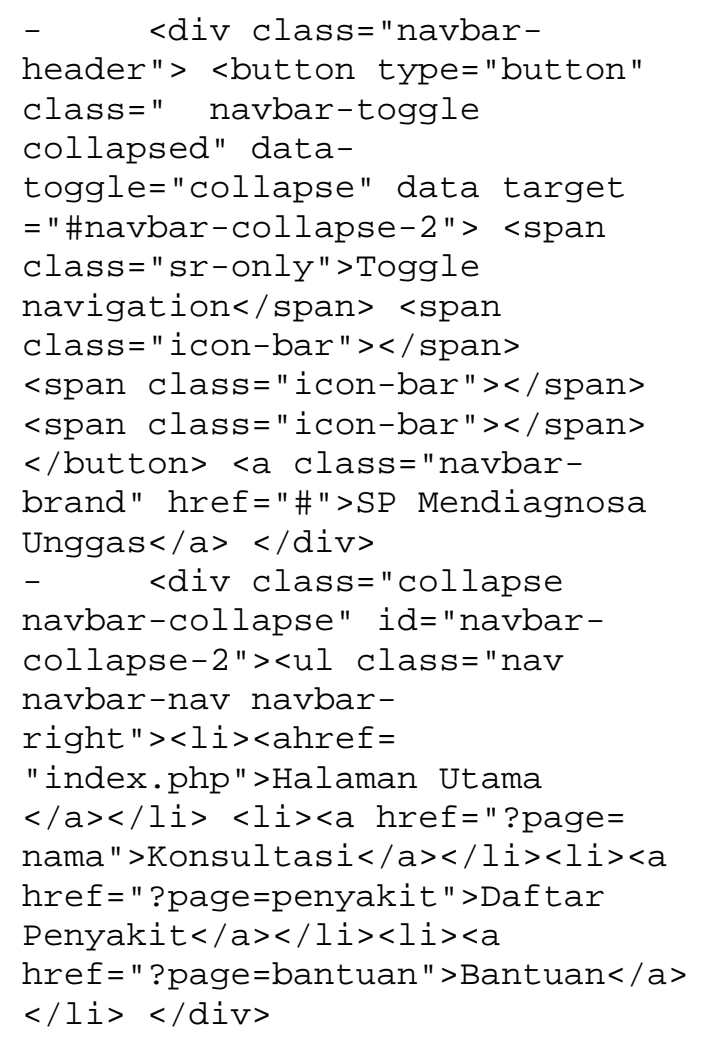

\section{Keterangan}

1. segmen coding pertama digunakan untuk memunculkan menu utama program.

2. segmen coding kedua digunakan untuk memunculkan menu konsultasi, daftar penyakit penyakit, dan bantuan.

\section{Segmen program menu konsultasi}

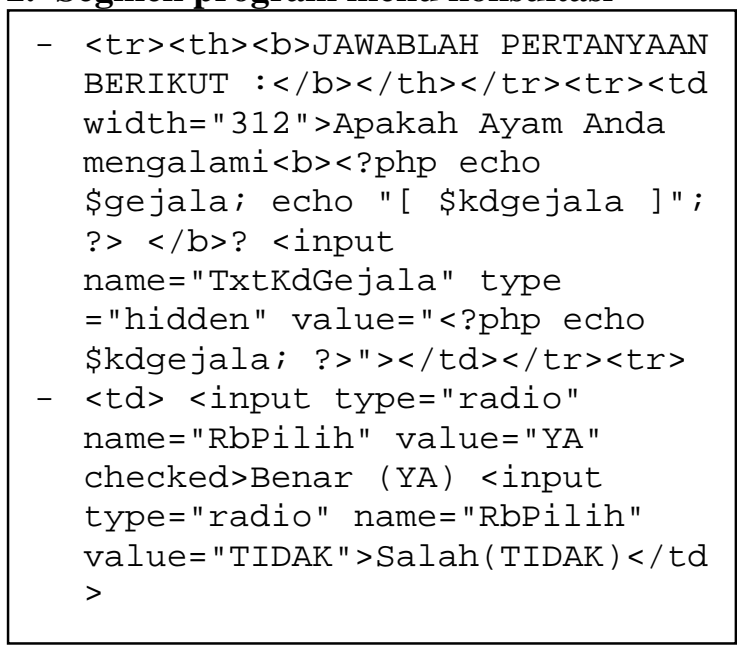


- $\langle$ td $>$ <input class="btn btnsuccess raised" type="submit" name $=$ "Submit "value $=$ "Jawab" $></ t$ $\mathrm{d}></$ tr $><$ tr $><$ td $>\&$ nbsp; $</$ td $></$ tr $><t r><$ th $><$ strong $>$ GEJALA YANG TERPILIH YA (BENAR) $</$ strong $></$ th $></$ t $r><$ t $r><$ t $d>$

\section{Keterangan}

1. segmen coding pertama digunakan untuk menampilkan pertanyaan penyakit.

2. segmen coding kedua digunakan untuk menampilkan pilihan ya dan tidak.

3. segmen coding ketiga digunakan untuk menampilkan pilihan gejala yang ada dalam relasi penyakit.

\section{KESIMPULAN}

Dari hasil penelitian dan perancangan pada bab sebelumnya maka penulis dapat mengambil kesimpulan diantaranya sebagai berikut: Aplikasi sistem pakar mendiagnosa penyakit pada unggas dengan metode teorema bayes berbasis web. Dari hasil ujicoba aplikasi dengan menggunakan blackbox testing semua tombol dalam aplikasi dapat berjalan dengan baik. Dari Aplikasi yang dibuat dapat melakukan identifikasi penyakit berdasarkan gejala yang sudah ada. Pada pengujian dari 10 peternak peternak menyatakan bahwa aplikasi ini dapat membantu mendiagnosa penyakit pada unggas. Dari hasil penelitian teorema bayes penyakit perbanyak pada unggas yaitu penyakit snot dengan jumlah $70 \%$.

\section{REFERENSI}

[1] Bayes . Thomas. 1763. Definisi Theorema Bayes. Diakses Dari: https://www.idomaths.com lid/peluang5.php. Jumat 19 Mei 2017.

[2] Buana. Setia. 2014. Jago Pemrograman PHP. Dunia Komputer, Jakarta Timur.

[3] Nafi'iyah. Nur. 2017. Komputer Cerdas untuk Mahasiswa Informatika. CV Budi Utama, Yogyakarta

[4] Lukito. Muhammad. 2016. Pengertian dan Bagian-Bagian Xampp. Diakses dari:http//DosenPendidikan.com. Selasa. 16 Mei 2017. 